\title{
WIZERUNEK FILOZOFA GRECKIEGO JAKO TRANSKOMUNIKATORA ZARZĄDZAJĄCEGO ZASOBAMI JEZYYKOWYMI I POZAJĘZYKOWYMI
}

\author{
KRYSTYNA TUSZYŃSKA
}

Na wstępie wymaga wyjaśnienia pojęcie ,wizerunek” w moim szkicu zagadnień komunikacyjnych, z jakimi mamy do czynienia w działaniach greckich sofistów i filozofów okresu starożytności. Termin, jako taki, używany jest w języku polskim $\mathrm{w}$ trzech kontekstach komunikacyjnych ${ }^{1}$. Podstawowe znaczenie powiązane zostało ze sztukami plastycznymi i wyobrażeniem graficznym kogoś, co pozwala na mówienie o podobiźnie, upostaciowieniu, wyobrażeniu, portrecie. Drugie znaczenie, które uznałam za najbliższe niniejszemu studium, oznacza kreowanie na użytek publiczny wyobrażenia jakieś osoby lub instytucji, zwłaszcza cieszacej się duża popularnościa. Bliskoznacznym terminem jest w tym wariancie obraz, image. Trzecie znaczenie, najbardziej mimetyczne, przywołuje na myśl odzwierciedlenie czegoś, odtworzenie czegoś, wiąże się, więc bardziej z przedmiotem (czymś) niż z człowiekiem (kimś).

Jako hellenistka staram się znaleźć w języku greckim termin adekwatny do polskiego ,wizerunku”. W tych poszukiwaniach należy wyjść od greckiego rdzenia słownego eid- ${ }^{2}$, służącego do tworzenia form czasownikowych, rzeczownikowych

\footnotetext{
${ }^{1}$ Definicje pojęcia „wizerunek” według Praktycznego Słownika Współczesnej Polszczyzny, tom 45, Wydawnictwo Kurpisz, Poznań 2004, s. 418.

${ }^{2} \mathrm{~W}$ zasadzie mamy do czynienia z czasownikiem idein (pierwotnie: Fidein) - widzieć, który pierwotnie odnosił się do widzianego kształtu rzeczy i oznaczał „formę”. Od niego wzięła swój rodowód Platońska „idea”. Na temat znaczeń idein zob. Wstęp Kazimierza Leśniaka do: Arystoteles, Dzieła
} 
i przymiotnikowych, których cechą wspólną jest „bycie widzianym”, „bycie postrzeganym" ze względu na kształt, formę, naturę, charakter, gatunek, wreszcie urodę. Oto kilka przykładów czasowników, rzeczowników i przymiotników utworzonych od rdzenia eid-:

Czasowniki:

eido - widzieć, ogladać, doświadczyć, doznać, pass. być widzianym, wydawać się, zdawać się, upodobnić się;

eido-poieo - nadać ksztatt, charakteryzować;

eidolo-poieo - tworzyć w myśli, wyobrażać sobie, sportretować;

Rzeczowniki:

eidos (neutrum) - ksztalt, postać, natura, forma, uroda, rodzaj, charakter, styl; eidolon (neutrum) - widmo, widziadto, odbicie, wizerunek, wyobrażenie, twór imaginacji;

Przymiotniki:

eido-poietikos, -e, on - nadajacy cechy gatunkowe;

eido-poios, -on - specyficzny, tworzacy odrębnoś $c^{3}$

Pozostanę w moim artykule w kręgu greckiego rdzenia eid- ze szczególnym wyczuleniem na przymiotnik eidopoios jako „specyficzny, tworzący odrębność”, bowiem, jak pokażę, możemy wyszczególnić kilka typów wizerunków sofistów i filozofów greckich w ich roli transkomunikatorów zarządzających swoimi zasobami językowymi i pozajęzykowymi, funkcjonującymi w hybrydowym połączeniu modalności wokalno-słuchowej oraz modalności wizualno-dotykowej ${ }^{4}$. Ponieważ „filozofowanie", a dokładnie jego model, zależny jest od zmieniających się warunków życia społecznego, politycznego, kulturalnego, zawsze z symptomem chęci zaznaczenia swojej odrębności mentalnej i ambicjami jednostek uprawiających philosophia, wizerunek filozofa greckiego, w tym sofisty, odgrywającego szczególną rolę w przejściu z kultury oralnej do nowej technologii, jaką jest pismo, również ulegał przeobrażeniom na przestrzeni historii społeczeństwa greckiego. Zajmowanie się filozofią miało w Grecji różne cele, zawsze jednak powiązane z działaniem w obrębie pewnej niszy komunikacyjnej, jaką tworzyło audytorium, niekiedy wąskiego

wszystkie: Metafizyka, t. 2, PWN, Warszawa 1990, s. 611. Pierwotna digamma (F) zanikła, a fonetycznie oddawała ona polskie ' $w$ '.

${ }^{3}$ Wszystkie znaczenia według Słownika grecko-polskiego, tom 2 E-K, pod red. Zofii Abramowiczówny, PWN Warszawa 1960.

${ }^{4}$ Pojęcie ,transkomunikatora” wprowadzone zostało przez Stanisława Puppla do wiedzy o modelu ludzkiego potencjału komunikacyjnego, jako osoby, agensa komunikacyjnego, posiadającego zdolność zarządzania swoimi zasobami językowymi i pozajęzykowymi i funkcjonującego przez hybrydowe połączenie potencjału modalności wokalno-słuchowej oraz modalności wizualno-dotykowej. Zob. Puppel, 2016. S. „The politics of performativity in transcommunication and its communicative/expressive fitness: towards a general outline”. Scripta Neophilologica Posnaniensia XVI. 99-108. 
grona uprzywilejowanych odbiorców, jak miało to miejsce w Akademii Platona czy szkole retorycznej Izokratesa ${ }^{5}$, rywalizujących w modelu formowania człowieka greckiego ${ }^{6}$, niekiedy zaś audytorium w postaci szerokiego i bardzo zróżnicowanego intelektualnie, społecznie i wiekowo zbiorowiska ludzkiego, z czym spotykamy się w działalności sofistów, Sokratesa lub cyników. Ta druga grupa transkomunikatorów stosowała planowo i świadomie techniki komunikacyjne obliczone na szeroki przekrój możliwości odbiorczych publiczności, specjalnie redukując swój potencjał językowy lub podając go w akceptowalnym przez audytorium wariancie.

W celu rozszerzenia interpretacji wizerunku sofisty i filozofa greckiego posłużę się rozumieniem pojęcia „wizerunek” w ujęciu Stanisława Puppla ${ }^{7}$. Wizerunek zasadniczo przyjmuje postać stereoskopowej diady wyglądu-oglądu, która z jednej strony wymaga nieustannego podejmowania wysiłków ze strony agensa wizerunku do jego wytworzenia i podtrzymania, za pomocą dostępnych mu zasobów, z drugiej strony środowisko, w którym następuje akt komunikacji, dokonuje weryfikacji wizerunku w wymiarze społeczno-kulturowym. Tym samym możemy powiedzieć, że wizerunek, jego posiadanie, skupianie się nad nim i pielęgnowanie go zawierają się w dynamice życia ${ }^{8}$, w przypadku mojego studium obecne są w wymiarze społecznokulturowym w obszarze wczesnych, klasycznych i hellenistycznych uwarunkowań uprawiania filozofii w Grecji.

Skupię się na kilku wybranych, i w mojej opinii, reprezentatywnych, wizerunkach filozofa greckiego: (1) z tzw. okresu presokratejskiego na wizerunku Pitagorasa, który określiłabym mianem „mistrza za zasłoną”, (2) wizerunku Heraklita z Efezu, który jest symbolem dobrowolnej separacji i wyalienowania z uwarunkowań społecznych i kulturowych, (3) w okresie przechodzenia kultury oralnej w kulturę słowa pisanego - na wizerunku sofisty, typowego komunikatora hybrydowego, operującego modalnością wokalno-słuchową oraz wzrokowo-dotykową, wraz z wyko-

\footnotetext{
${ }^{5}$ Izokrates domagał się dla siebie miana filozofa, którego odmawiał mu Platon, i prowadził elitarną szkołę, w której nauczanie wymowy było równoznaczne z nauczaniem cnoty, arete, ponieważ, zdaniem Izokratesa, przemawianie w sprawach etycznie szczytnych czyni samego mówcę człowiekiem lepszym moralnie. Na temat celów stawianych sobie przez Izokratesa w procesie edukacyjnym zob. Hadot, P. 1984. Arts liberaux et philosophie dans la pense antiqua. Paris, s. 16-18.

${ }^{6} \mathrm{Z}$ owej rywalizacji obronną ręką wyszła koncepcja Izokratesa, ponieważ stawiała przed uczniami zadania wykonalne i praktyczne, rozwijała umiejętność podejmowania decyzji, wyczucie intuicyjne w zawikłanym położeniu, umiejętność uchwycenia tych imponderabiliów, które kierują poglądami (doksa) i czynią je trafnymi. Kultura filozoficzna i kultura retoryczna są w wychowaniu greckim nie tylko dwiema rywalkami, ale też dwiema siostrami. Spór o model wychowania wzbogacił tradycję antyczną, nie naruszył jednak jej jednolitości. „Zmysł geometryczny” Izokratesa zwyciężył nad „,zmysłem wysubtelnionym" Platona. Na temat rywalizacji dwóch modeli wychowania w starożytności zob. Marrou, H.I. 1969. Historia wychowania w starożytności, tłum. S. Łoś, Warszawa. s. 142-145.

${ }^{7}$ Zob. Puppel, S. 2016. „Kuźnia Hefajstosa, czyli krótki zarys teorii wizerunku w komunikacji człowieka”. Scripta Neophilologica Posnaniensia XVI. 109-124.

${ }^{8}$ Idem, s. 110.
} 
rzystaniem wszystkich możliwych zasobów komunikacyjnych nastawionych nad maksymalizację fortunności aktu komunikacji w zróżnicowanym obszarze publicznym, (4) na wizerunku Sokratesa, który upublicznił i sprowadził do oglądu masowego wizerunek filozofa, świadomy nowej roli filozofii w życiu społeczności greckiej oraz (5) na wizerunku cynika, który czuje się już obywatelem świata i z całą świadomością tego przedsięwzięcia uniezależnia się od opinii greckiej polis, kurczącej się pod naporem nowych sił politycznych, a tym samym, starannie i konsekwentnie buduje, jakby mimowolnie i na przekór, wizerunek filozofa-kosmopolity, nieobojętnego na niepokoje innych ludzi, pełniącego funkcję ,lekarza dusz”.

\section{Wizerunek filozofa presokratejskiego}

Pierwsi filozofowie greccy, tak zwani presokratycy, jawią się nam w dwóch postaciach -jońskiej i italskiej, co związane było z migracją myślicieli greckich przed naporem perskim na Jonię: wojny perskie spowodowały zniszczenie miast jońskich, przerwały rozkwit naukowy Jonii i zmusiły do szukania nowego środowiska dla nauki ${ }^{9}$. Oba nurty nieco rozchodziły się w pojmowaniu zadań filozofii: jońska nawiązywała w szerszym stopniu do umiejętności przedfilozoficznych, natomiast italska czerpała z wierzeń i mitów religijnych ${ }^{10}$. Stąd też narodziły się dwa nurty - joński bardziej empiryczny, italski - raczej spekulatywny. Możemy również, moim zdaniem, już na tym etapie rozwoju myśli greckiej, tzn. VII i VI wieku p.n.e., wyodrębnić dwa wizerunki filozofa greckiego - „mędrca jońskiego” oraz „kontemplatora italskiego”. Ten drugi typ filozofa mieści w swoim wizerunku także cechy „filozofa -autorytetu". Obaj jednak wypracowali podobny wizerunek jako komunikatorzy niedostępny dla szerokiego audytorium, wręcz przeciwnie - pielęgnujący wizerunek mędrca niedbającego o fortunność aktu komunikacji, niechętnego do przystosowywania języka wypowiedzi do średnich lub niskich rejestrów języka, a nawet świadomie utrudniającego próby zbliżenia między komunikatorem a odbiorcą.

Wizerunek ,filozofa-autorytetu” zapoczątkował Pitagoras, a później kultywował pitagoreizm, jako całość ruchu naukowego, pozostający pod silnym wpływem wierzeń religijnych i misteriów orfickich. Pitagorasowi zawdzięczamy opisowe oddanie roli filozofa i filozofii jako sztuki kontemplacji. Ludzie - według Pitagorasa - dzielą się na trzy grupy ze względu na uprawiany styl życia, odpowiadające trzem katego-

\footnotetext{
${ }^{9}$ Filozofia narodziła się w Milecie, bogatym mieście na skrzyżowaniu szlaków handlowych z Egiptu, Fenicji i Cypru - na północ w kierunku Morza Czarnego oraz w kierunku zachodnim, prowadzącym do Grecji śródlądowej i na Kretę. Według Arystotelesa (Metafizyka 981 b, ks. A) było to miejsce właściwe dla narodzin umiejętności, które nie mają na celu ani przyjemności fizycznych, ani korzyści materialnych, a przeciwnie - służą wytchnieniu i mogą powstać tylko tam, gdzie obywatele dysponują wolnym od zajęć czasem i nie spędzają go na zabiegach związanych z utrzymaniem.

${ }^{10}$ Tatarkiewicz, W. 1978. Historia filozofii t. 1. Warszawa: PWN. s. 22.
} 
riom osób biorących udział $\mathrm{w}$ igrzyskach olimpijskich: na najniższym poziomie stoją ci, którzy przychodzą na igrzyska kupczyć: sprzedać coś lub nabyć; drugą grupę tworzą ci, którzy biorą bezpośredni udział w igrzyskach, stając do rywalizacji; do trzeciej grupy należą ci, którzy przyszli tylko popatrzyć, widzowie przyglądający się igrzyskom, są to 'teoretycy' (od gr. czasownika theaomai, 'patrzeć', 'oglądać', 'jasno pojacé, 'rozważać'). Ich rola jest analogiczna do roli filozofów. Jak przekazuje Diogenes Laertios: podobnie jest $w$ życiu: jedni sq niewolnikami stawy, inni wta$d z y$, inni natomiast filozofami i szukajacymi prawdy ${ }^{11}$. Poszukiwanie prawdy łączy się w nauce pitagorejskiej z licznymi tabu i surowymi zasadami, których musieli przestrzegać uczniowie Pitagorasa, zrzeszeni w bractwie pitagorejskim, thiasos. Pojęcie to tłumaczone jest na język polski przez 'sekta', 'zakon', 'klub'12, zorganizowany według bardzo ścisłych reguł współżycia, w którym nauka jest wspólnym dobrem, strzeżonym jako sekret. Z dobra tego czerpali wszyscy adepci i starali się je powiększyć prowadząc wspólne poszukiwania i badania ${ }^{13}$ szczególnie w dziedzinie matematyki. W gronie Pitagorejczyków wyłonić można dwie grupy: jedni przylgnęli to tradycji mistycznych i religijnych (reinkarnacja, oczyszczenie) i nazywali siebie 'akuzmatykami', drudzy oddali się nauce i nazwali się 'matematykami' ${ }^{14}$. Nie mniej jednak od obu odłamów pochodzi pojęcie bios theoretikos, czyli życie kontemplacyjne, zwane do dziś „życiem pitagorejskim”, które szuka oczyszczenia w kontemplacji prawdy, oparte jest na wiedzy, ascezie i poznaniu. Medyczne reguły oczyszczenia i ascetyczne reguły abstynencji miały na celu oczyszczenie ciała, po to, aby uczynić je uległym nieśmiertelnej duszy, dla której ciało jest tylko więzieniem ${ }^{15}$. Najistotniejsze jednak dla mojego studium są metody przekazywania wiedzy oraz komunikowania się mistrza z uczniami. Nowicjusze, po przyjęciu do bractwa/zakonu Pitagorejczyków, musieli jedynie milczeć i słuchać, co uważano za umiejęt-

${ }^{11}$ Laertios, D. 1982. Żywoty i poglady stynnych filozofów (ks. VIII, 8), przekład Irena Krońska, Kazimierz Leśniak, Witold Olszewski, Bogdan Kupis. Warszawa.

${ }^{12}$ To ostatnie znaczenie używane jest przy charakterystyce związku aktorów w Grecji, którzy tworzyli thiasos pod wezwaniem Dionizosa, bóstwa opiekuńczego teatru. Zadaniem aktorów zrzeszonych w 'klubie' było przestrzeganie surowej diety w jedzeniu i napojach oraz dbanie o swoje głosy (aktorzy mieli sporo partii śpiewanych, także solo, tzw. monodii). Natomiast przywilejem aktorów było zwolnienie od płacenia podatków oraz służby wojskowej (piękny głos był bardzo cenny). Podobnie Akademia Platońska zorganizowana była na zasadzie thiasos pod wezwaniem boga Apollona, także szkoła dla panien na wyspie Lesbos, prowadzona przez Safonę, miała charakter thiasos pod wezwaniem bogini Afrodyty.

${ }^{13}$ Badania te dostępne były tylko dla zrzeszonych w związku pitagorejskim, traktowane jako sekret, co czyniło je niedostępnymi dla innych i było nowością w szkołach filozoficznych powstających w Grecji. Poza tym mówimy o 'związku', ponieważ nie można oddzielić samego Pitagorasa od uczniów: Pitagoras niczego nie napisał i bardzo mało informacji jest o nim potwierdzonych, natomiast według Żywota Pitagorasa zatracił cechy ludzkie w pojęciach uczniów i był czczony jako bóstwo, być może już w ostatnich latach swego życia.

${ }^{14}$ Por. Tatarkiewicz, W., op. cit., s. 54.

${ }^{15}$ Reale, G. 1993. Historia filozofii starożytnej, t. I. przełożył Edward Iwo Zieliński. Lublin, s. 121. 
ności najtrudniejsze do przyswojenia. To znaczy, że w początkowej fazie „filozofowania" adepci pitagoreizmu zmuszeni byli ograniczyć swój potencjał komunikacyjny do modalności słuchowej. Dopiero, gdy opanowali tę umiejętność, mogli zadawać pytania, dowiadywać się o problemy dotyczące muzyki, arytmetyki, geometrii, a nawet zapisywać sobie to, czego się dowiedzieli. Tym samym włączała się sfera modalności wokalnej. Hybrydowy zaś charakter komunikacji pitagorejskiej polega na tym, że modalność słuchowo-wokalna łączy się z modalnością wizualno-dotykową w momencie, gdy mistrz pitagorejski przekazuje wiedzę ukryty za zasłoną, jak gdyby symbolem oddzielenia wiedzy od osoby, która ją przekazywała, a przede wszystkim w celu wytworzenia układu hieratycznego. Formuła, przy pomocy której nauczający przekazywał wiedzę brzmiała: gr. autos ephe, łac. ipse dixit, 'on sam powiedział' (domyślnie: boski Pitagoras). Formuła ta stała się powszechnym symptomem komunikacji w pitagorejskim thiasos, a nauczany był zobowiązany do zachowania nauki w sekrecie ${ }^{16}$. Nietrudno zauważyć, że w obrębie ludzkiego potencjału komunikacyjnego mamy do czynienia z językiem idiosynkratycznym, wysoce zindywidualizowanym, właściwym osobie mistrza pitagorejskiego i strzeżonym przed niewtajemniczonymi.

Ten sam, idiosynkratyczny język, będący przejawem środowiska wewnętrznego w akcie komunikacji, obserwujemy w odgałęzieniu przedsokratejskiej filozofii jońskiej, w osobie najoryginalniejszego jej myśliciela, Heraklita z Efezu, do którego przylgnęło określenie „,ciemnego filozofa”. Czesław Miłosz poświęcił wiersz Heraklitowi i jego silnie zindywidualizowanej syntaksie:

Litowat się nad nimi, sam godzien litości.

Bo to jest poza wyrazami jakiegokolwiek języka.

Nawet sintaxis, ciemna, jak ти zarzucano,

Stowa tak ułożone że z potrójnym sensem,

Niczego nie obejma. $[\ldots]^{17}$

W wierszu Miłosza nie brakuje również zabiegów syntaktycznych naśladujących „,iemny” styl filozofa z Efezu. Heraklit, znany z zagadkowych wypowiedzi, otrzymał przydomek skoteinos ('ciemny', 'mroczny'), lub też ainiktes, 'mówiący zagadkami' ${ }^{18}$. Jego dzieło ma jedyną w swoim rodzaju formę podawczą: trudnych do zrozumienia aforyzmów-orędzi. Mrok tej wieloznaczności rozjaśnia do pewnego stopnia okoliczność, że na dnie każdego prawie aforyzmu znajduje się myśl o jedności (tożsamości) przeciwieństw. Myśl tę Heraklit głosi w coraz to innych słowach, porównaniach, skojarzeniach, z entuzjazmem zbliżonym do fanatyzmu: Nieśmiertelni śmiertelni, śmiertelni nieśmiertelni - żywi śmiercia tamtych, a życiem tamtych zmarli

\footnotetext{
${ }^{16}$ Reale, G. Historia filozofii starożytnej, t. I, op. cit., s. 120.

${ }^{17}$ Początek wiersza Czesława Miłosza Heraklit wg wydania: Miłosz, Cz. 1983. Poezje. Warszawa: Czytelnik, s. 251.

${ }^{18}$ Por. Krokiewicz, A. 1971. Zarys filozofii greckiej. Od Talesa do Platon. Warszawa, s. 132.
} 
(frg. B 62) ${ }^{19}$. Heraklit świadomie utrudniał czytelnikom zrozumienie swego dzieła. $\mathrm{Z}$ pewnością można go zakwalifikować w obrębie komunikatora charakteryzującego się syndromem Petroniusza, to znaczy administratora wysokiej jakości zasobów językowych, ale jednocześnie wykazującego niską zdolność, jako transkomunikator, do adaptacji środowiskowej ${ }^{20}$. Heraklit, przekonany o trafności swoich poglądów, spotkał się w Efezie z lekceważeniem. Znany, jako ‘dumny’ (hyperoptes) ${ }^{21}$, żywił głęboką pogardę dla pospólstwa, czego świadectwem jest zachowany fragment: Najlepsi przenosza jedno nad wszystko; wieczna sławe nad doczesne dobra, podczas gdy ttum lubuje się w sytym brzuchu na podobieństwo bydła (frg. B 29). Konsekwentnie, zamierzał swoją naukę udostępnić tylko nielicznym, którzy się na jej głębi poznają. Kul, zatem swoje aforyzmy, z których wiele ma charakter symboliczny, często wielowątkowo interpretowany, jak na przykład aforyzm: do tej samej rzeki nie można wejść dwa razy (frg. B 91): Jedni mówią, że Heraklit miał na myśli nieodwracalność ruchu, której polegały niezmienne prawa i ład świata, i równocześnie wewnętrzną jedność wszystkiego, co istnieje. Inni twierdzą, płyciej, iż Heraklit miał na myśli zmienność zarówno ludzi, jak i rzeki toczącej wciąż nowe wody ${ }^{22}$. Czesław Miłosz cytując Diogenesa Laertiosa usiłuje wytłumaczyć zachowanie Heraklita, jako autora aforyzmów:

"Nikt jak on nie byt dumny i wzgardliwy".

Bo torturowat siebie, wybaczyć nie mogac,

Że chwila świadomości nigdy nas nie zmienia.

Litość dosiegła gniewu. Aż uciekt z Efezu.

Twarzy ludzkiej ogladać nie chciat. Mieszkat w górach.

Jadt trawę i listowie, powiada Laertius.

Miłosz kończy wiersz refleksją:

Pod stromym brzegiem Azji morze ktadto fale

(z wysoka fal nie widać, widać tylko morze).

To podane w nawiasie dopowiedzenie stanowi poetycką interpretację całej filozofii Heraklita: naszym zmysłom dostępne są tylko pozory rzeczy, ich istota pozostaje ukryta. Heraklit posiadał świadomość znikomości ludzkiej mądrości, opartej na postrzeżeniach zmysłowych. Ostrzegał człowieka wyposażonego w dwa organy

${ }^{19}$ Cytat za Krokiewicz, A., op. cit., s. 132.

${ }^{20}$ Syndrom Petroniusza został wprowadzony do nauki o komunikacji przez Stanisława Puppla $\mathrm{w}$ The politics of performativity in transcommunication and its communicativelexpressive fitness: towards a general outline, op. cit., s. 106-107.

${ }^{21}$ Diogenes Laertios przekazuje, że „,był wyniosły jak mało kto i pogardliwy”, jak to wynika z jego dzieła, w którym mówi, że „Nie wystarczy dużo wiedzieć, żeby być mędrcem; rozległa wiedza nie nauczyła mądrości ani Hezjoda, ani Pitagorasa, ani Ksenofanesa, ani Hekataiosa" (ks. IX, 1, 1) według przekładu Ireny Krońskiej.

${ }^{22}$ Interpretacje wg Krokiewicz, A., op. cit., s. 135. 
poznania, zdolność zmysłowego postrzegania (aisthesis) i zdolność rozumnego myślenia (logos) przed ślepą wiarą w rzekomą prawdę 'nierozumnych zmysłów', kiedy pisał: Złymi świadkami sq oczy i uszy dla ludzi, jeśli maja barbarzyńskie dusze (frg. B 107). Ludzki, osobniczy rozum nie jest kryterium prawdy, ale dusza ludzka ma łączność z otaczającym światem i rozumie jego mowę - człowiek uczestniczy we wspólnym i boskim rozumie (koinos kai theos logos). Rozum ten kieruje ładem całego świata i dopiero on stanowi kryterium prawdy ${ }^{23}$.

„Mowa” była również jednym z podstawowych symboli w filozofii Heraklita, wyrażającym zmienność i płynność pozorną, oraz niezmienną istotę: oto poszczególne wyrazy danego zdania (epea) ,płyną" i kiedy słyszymy pierwszy, nie ma jeszcze dalszych, kiedy słyszymy środkowy, nie ma już poprzednich, a kiedy słyszymy koniec zdania, nie ma już ani jego środka, ani początku, ale tworzy się sens (logos) zdania. Logos jest jeden i chociaż tkwi w każdym z przemijających wyrazów, nie przemija wraz z nimi; podobnie „płynie” zmienna rzeczywistość zmysłowa świata i podobnie trwa jej sens niezmienny ${ }^{24}$.

Nawiązując do historii życia Heraklita, poetycko opowiedzianej przez Miłosza, jego gest ucieczki z Efezu, samotnego bytowania w górach i żywienia się roślinami i ziołami ${ }^{25}$, również uznać należy za akt komunikacji niewerbalnej, wzgardy wobec pospolitych mieszkańców Efezu.

Obaj przedstawiciele filozofii presokrateskiej, która ogniskowała swoje zainteresowania wokół kwestii epistemologicznych i ontologicznych, nadto wykształciła typ filozofa-samotnika z wyboru, jakim był Heraklit, czy filozofa (żyjącego wprawdzie w bractwie, thiasos, ale silnie zhierarchizowanym) - autorytetu i uprawiającego filozofię jako sacrum, ukrytego za zasłoną, która symbolicznie wyznaczała linię demarkacyjną między niedouczonym adeptem a mistrzem przekazującym wiedzę, reprezentują wizerunek filozofa-komunikatora z syndromem Petroniusza. Nadto sam thiasos gromadził „wybrańców”, którzy za osiągnięcie wtajemniczenia odpłacali życiem wypełnionym ascezą i wspólną pracą badawczą, zazwyczaj anonimową, której rezultaty objęto wspólną nazwą ,filozofii pitagorejskiej”.

W przypadku filozofów presokratejskich łatwiej mówić o statycznym rozumieniu wizerunku, jako silnie rozwiniętej świadomości odnośnie własnej, indywidualnej

\footnotetext{
${ }^{23}$ Warto dodać, że założyciel szkoły stoickiej, Zenon z Kition oparł na tym twierdzeniu Heraklita całą swoją fizykę z boskim, choć materialnym Logosem, który kieruje całym światem (pierwszy system panteistyczny w filozofii europejskiej), a człowiek rozumny podporządkowuje swoje życie boskiemu Logosowi, uzyskując tak cnotę i szczęście, które są pojęciami synonimicznymi. Poprzez pneumę, która jest tworzywem duszy (dusza ludzka w stoicyzmie jest materialna) człowiek uczestniczy w boskim Logosie.

${ }^{24}$ Interpretacja fragmentu B 1 Heraklita za Adamem Krokiewiczem, op. cit., s. 135.

${ }^{25}$ Heraklit nabawił się w ten sposób puchliny wodnej, a próbując ją wypocić w ciepłym krowim gnoju, zmarł w wieku 60 lat. Zob. Laertios, D. Żywoty i poglądy stynnych filozofów, op. cit., ks. IX, rozdz. 1, 3 .
} 
tożsamości, trudniej natomiast o dynamiczne rozumienie wizerunku, zgodnie z którym filozof presokratejski podejmowałby różne działania interakcyjno-komunikacyjne, które miałyby na celu nieustanne wytwarzanie u odbiorcy określonych wra$\dot{z ̇ e n}^{26}$. Wydaje się, że wręcz przeciwnie, presokratykom nie zależało na interakcji ze społeczeństwem, inaczej mówiąc, z pospólstwem, którym gardzili i od którego separowali się bądź symboliczną zasłoną, bądź niezrozumiałą syntaksą wypowiedzi. Filozofia, zgodnie z porównaniem Pitagorasa, miała przeznaczenie teoretyczne, „oglądowe” i dotyczyła nielicznej grupy, która z jej uprawiania nie ciągnęła żadnych korzyści materialnych i strzegła jej niczym skarbu.

\section{Wizerunek sofisty}

W V w. p.n.e. w Grecji, w nowych realiach politycznych, społecznych i kulturowych, pojawili się sofiści. Stopniowa demokratyzacja życia w Atenach, jako duchowej stolicy Hellady, sprawiła, że pojawił się popyt na wiedzę, nawet, jeżeli była to wiedza importowana, jak w przypadku sofistów pochodzących z różnych zakątków świata greckiego. Powszechny udział obywateli we władzach ustawodawczych i sądowniczych zaowocował koniecznością wyuczenia się technik komunikacyjnych, ułatwiających sprawowanie urzędów i gwarantujących odniesienie sukcesu politycznego. Filozofia w okresie tzw. oświecenia greckiego przestaje posiadać znamiona sacrum przede wszystkich za sprawą zmiany nastawienia jej dysponentów do obszaru komunikacji, który się upublicznia. W szeroko pojętym interesie sofistów leżało podejmowanie różnych działań interakcyjno-komunikacyjnych i wszelkich wysiłków w celu wytworzenia i utrzymania korzystnego dla siebie wizerunku. Nie będąc obywatelami miast, do których przybywali, i równocześnie posiadając wysokie ambicje oddziaływania na życie społeczne i kulturalne w tych miastach, korzystali ze wszystkich dostępnych im zasobów komunikacyjnych, aby uczynić swój wizerunek atrakcyjnym dla obywateli i łatwym w sprzedaży.

Należy powiedzieć o sofistach zarówno w kontekście niewerbalnych aktów komunikacji, jak i w kontekście komunikatora o pozornym tzw. syndromie Guliwera. Mam na myśli fakt, że sofiści, jako wędrowni i płatni nauczyciele mądrości, każdorazowo dostosowywali swoje zasoby językowe do konkretnego aktu komunikacyjnego. Proponowali dwie formy przekazu: wykład na ustalony z góry temat, ewentualnie temat podsunięty przez audytorium oraz metodę dyskusji z publicznością, czyli pytań audytorium i odpowiedzi sofisty. Musieli dysponować bardzo bogatym zasobem językowo-komunikacyjnym, skoro sofista Gorgiasz w Platońskim dialogu biorącym tytuł od jego imienia jest bardzo pewny swoich możliwości komunikacyjnych:

\footnotetext{
${ }^{26}$ Rozumienie „dynamizmu wizerunku” według koncepcji Stanisława Puppla w: Kuźnia Hefajstosa, op. cit., s. 111.
} 
Chajrefont: [...] Powiedz mi Gorgiasie, czy prawdę mówi obecny tu Kallikles, który obiecat, że odpowiesz na każde pytanie, jakie ktokolwiek ci zada?

Gorgias: To prawda Chajrefoncie. Nawet w tej chwili mówitem publicznie to samo, i dodam, że od wielu lat nikt nie zapytat mnie o coś, co bytoby dla mnie nowym ${ }^{27}$.

Syndrom Guliwera jest w przypadku sofistów, moim zdaniem, syndromem pozornym, przyjętym na potrzeby zaistnienia w greckich poleis, do których przybywali. Jako nie-obywatele nie mogli przemawiać na zgromadzeniach ludowych, nie mogli uczestniczyć w ateńskim sądzie ludowym, heliai, ich domeną pozostawały publiczne pokazowe występy (public display lecture), nacechowane teatralnością (performance), która przejawiała się w gestykulacji oraz w stroju. Sofiści przywdziewali na popisowe występy purpurowe szaty rapsoda, aby zasygnalizować swoje prawo do przejęcia w greckiej społeczności funkcji poety-aojdy, którego wiersze były memoryzowane przez społeczność i stanowiły wykładnię etyczną zachowań społecznych. Sofiści posiadali wysoką jakość zasobów komunikacyjnych, każdego z nich cechowały pionierskie badania. Gorgiasz zasłynął z zainteresowań logosem jako elementem nie tylko komunikacji, ale też podstawą rozwoju myśli ludzkiej przez coraz lepiej wyposażone w siłę perswazyjną argumenty, jest też twórcą iluzjonistycznej koncepcji sztuki, zgodnie z którą artysta wprowadza w odbiór sztuki element oszukaństwa, ułudy, który jednak wpisuje się we wszelką kreatywną działalność człowieka ${ }^{28}$, stworzył także artystyczną prozę grecką, bogato ozdobioną środkami ornamentacyjnymi zapożyczonymi z poezji. Nie jest to niezrozumiałym zabiegiem, biorąc pod uwagę powszechne w społeczeństwie greckim przekonanie o sile oddziaływania słowa poetyckiego, memoryzowanego przez audytorium i pełniącego funkcję zasobu wskazówek mówienia i działania. Gorgiasz, obserwując sukces epiki i tragedii, wyposażył artystyczną prozę grecką w figury retoryczne, nazwane od jego imienia schemata Gorgieia, zrytmizowane części wypowiedzi, rymy wewnętrzne, tzw. homoioteleuta, polegające na takim samym lub rymowanym zakończeniu okresów zdaniowych, isokola, czyli wymóg równej liczby sylab w okresie retorycznym. Wszystkie te zdobycze podyktowane były dbałością o eufonię i płynącą z niej przyjemność dla słuchacza ${ }^{29}$. Bez wątpienia możemy mówić w przypadku Gorgiasza o mistrzowskim wykorzystaniu modalności wokalno-słuchowej. Jego lingwistyczną kompetencję wspierały zasoby pozajęzykowe, do których w pierwszej kolejności należy zaliczyć przywdziewane na występy purpurowe szaty rapsoda ${ }^{30}$,

\footnotetext{
${ }^{27}$ Platon, Gorgias. Menon, przełożył, wstępem i komentarzem opatrzył Paweł Siwek, Warszawa 1991, s. 8 (447 d-448 a).

${ }^{28} \mathrm{Na}$ ten temat zobacz: Tuszyńska-Maciejewska, K. 1989. „Gorgias APATE as an inevitable and justified error of man's aesthetic activity”. Acta Universitatis Scientiarum Debrecenensis XXV. 19-22.

${ }^{29}$ Zob. Tuszyńska, K. 2016. Oratorstwo i retoryka grecka z wyborem tekstów źródłowych. Od oralnej kultury retorycznej Homera do konceptualizacji retoryki przez Arystotelesa. Poznań, s. 77-78 oraz 153-154.

${ }^{30}$ Kerferd, G.B. 1984. The Sophistic Movement. Cambridge, s. 29. Kerferd potwierdza fakt przywdziewania purpurowych szat rapsoda dla Gorgiasza i Hippiasza, powołując się na fragment 82 A9 Dielsa-Kranza, Die Fragmente der Vorsokratiker.
} 
a także okoliczności publicznych wystąpień, to znaczy uroczyste igrzyska pytyjskie i olimpijskie oraz teatr ateński ${ }^{31}$. Podniosły nastrój tego rodzaju self-presentation współtworzył nielingwistyczną kompetencję komunikacyjną. Pojęcie wizerunku w tym miejscu należy pogłębić przez zaakceptowanie diady wygląd - ogląd ${ }^{32}$, ponieważ purpurowe szaty i miejsce występu epideiktycznego (gr. epideiksis, ang. distict type of performance, public display lecture) stanowiły sygnał wysyłany przez sofistę na zewnątrz, ku obserwującej i słuchającej go publiczności.

Z kolei sofista Prodikos zyskał sławę jako inicjator badań nad synonimiką, obrazowo przedstawionych $\mathrm{w}$ dyskusji Sokratesa $\mathrm{z}$ Prodikosem w Platońskim dialogu Protagoras (339 e-340 d). On też zdefiniował sofistów jako 'na wpół filozofów, na wpół polityków' (methoria philosophou te andros kai politikou (frg. B 6) ${ }^{33}$, ponieważ w domenie nauk udzielanych przez sofistów mieściły się zagadnienia, z którymi zmagała się filozofia wcześniejsza, to znaczy te o charakterze epistemologicznym, czy kosmogonicznym, podobnie jak pierwsze refleksje lingwistyczne, Heraklita, czy paradoksy szkoły eleackiej połączone były z dziedziną ontologiczną. W tym sensie sofiści uważali się za spadkobierców wcześniejszej myśli filozoficznej, co wszakże nie znaczy, że nie podchodzili do niej krytycznie, czy wręcz sceptycznie ${ }^{34}$. Natomiast w obrębie zainteresowań sofistów znalazły się również zagadnienia nowe dla filozofii, które dopiero torowały sobie miejsce w jej obszarze, a dotychczas należały do kwestii szeroko rozumianej polityki. Arystoteles nazwie człowieka w Polityce (1253 a 10) zoon politikon, czyli zwierzęciem społecznym, ponieważ żyjącym w ramach urządzeń społeczno-politycznych przyjętych przez grecką polis. Wśród nich istotną rolę odgrywał arsenał technik retorycznych, jako residuum oralne niezbędne w realizowaniu ambicji politycznych. Prodikos, zatem wskazuje na zainteresowania sofistów w dyscyplinach nowych w myśli filozoficznej, takich jak relacja na linii obywatel-państwo (jednostka-społeczeństwo), koncepcje wolności politycznej i równości ludzi, poszanowanie godności obywatelskiej, zagadnienie przywódcy państwowego, szeroko rozumiana antyteza nomos-physis ${ }^{35}$, prawo silniejszego,

\footnotetext{
${ }^{31}$ Ibidem, s. 28.
}

${ }^{32}$ Zob. Stanisław Puppel, Kuźnia Hefajstosa..., op. cit., s. 109. S. Puppel posługuje się terminem angielskim etic-emic, zaczerpniętym z prac K.L. Pike'a A stereoscopic window on the world (1957) oraz Language in relation to a united theory of the structure of human behavior (1967).

${ }^{33}$ Zob. Tuszyńska-Maciejewska, K. 1987. Filozofia w retoryce Gorgiasza z Leontinoj. Poznań, s. 8.

${ }^{34}$ Znamiona sceptycyzmu w europejskiej myśli filozoficznej znajdują się w traktacie Gorgiasza z Leontinoj Peri tou me ontos e peri physeos (O tym, co nie jest, czyli o naturze), w tytule nawiązującym do traktatów presokratyków Peri physeos, czyli $O$ naturze, wymierzonym przez Gorgiasza przede wszystkim przeciw szkole eleackiej. Poza tym sceptycyzm obecny jest w mowie epideiktycznej Gorgiasza Pochwała Heleny, kiedy Gorgiasz uzasadnia potęgę logosu, kreującego zgodnie z zamierzeniem autora najróżniejszego typu argumentacje, często sprzeczne między sobą, ale wyposażone w siłę perswazji (par. 13-14 Pochwaty Heleny).

${ }^{35}$ Przeciwstawienie prawa (nomos) i natury (physis) widoczne jest w wypowiedzi sofisty Hippiasza z Elidy w Platońskim dialogu Protagoras: Ja was tu wszystkich, szanowni zebrani, uważam za krew- 
często interpretowane w ramach tej antytezy. To, co było żywiołem życia politycznego, znajdowało swoje miejsce w powstających, nowych obszarach badań filozoficznych. Wymagało to od sofistów skutecznego zarządzania zasobami komunikacyjnymi, a jednocześnie, w demokratycznych Atenach, przemawiało na korzyść fortunności tego typu aktów komunikacji ze względu na wielkie zainteresowanie nową tematyką paidei, przydatną w życiu społeczno-politycznym. Sofiści, aby utrzymać te warunki fortunności harmonijnie przystosowywali zarówno treść, jak i sposób przekazu do zmieniających się okoliczności kulturowych: dawne wychowanie muzyczne (mousike paideia) sofiści zastąpili wychowaniem obywatelskim, opartym na politycznej arete, implikowanej przez logos, z całą wieloznacznością tego greckiego terminu (mowa - myśl - rozum) ${ }^{36}$. Także urozmaicona forma podawcza: wykład, dyskusja ze słuchaczami, sprzyjały komunikacji między sofistą a audytorium. Najstarszy i najsłynniejszy z sofistów, Protagoras, był zdania, że społeczeństwo dysponuje zasobem rozdzielania nagród i wymierzania kar i głosił optymistyczną tezę o zaszczepionemu człowiekowi poczuciu sprawiedliwości i rozsądku, które sprawiają, że arete obywatelskiej można każdego człowieka nauczyćc ${ }^{37}$. Tym samym Protagoras realizował nowe cele wychowawcze, także w pojmowaniu wymiaru sprawiedliwości ${ }^{38}$, a głoszone przez niego hasła dostępności arete politycznej dla wszystkich obywateli, niezastrzeżonej już tylko dla warstwy dobrze urodzonych, gwarantowały sofistom atrakcyjność w społeczeństwie greckim i zapewniały powodzenie aktu komunikacyjnego. Sami zaś sofiści, będąc dysponentami bogatych zasobów komunikacyjnych, świadomie i celowo zrezygnowali z nich na

nych, bliskich i wspótobywateli, nie wedle prawa (nomos), lecz z natury (physis). Bowiem istoty podobne sa sobie pokrewne z natury, a tylko prawo (nomos), które tyranem jest między ludźmi, narzuca im wiele rzeczy przeciwnych naturze. Platon, Protagoras 337 c. Przekład własny.

${ }^{36} \mathrm{~W}$ rezultacie proces wychowania, paideuein, rozszerzył swoje granice i doprowadził do rozumienia go jako formowania dorosłego człowieka - członka określonego kręgu społecznego, wyposażonego w umiejętności, które Rzymianie nazwą terminem cultura. Proces ten realizuje się w momencie uświadomienia sobie przez ludzi samej idei kultury i faktu, że świadomie działający duch ludzki potrafi poprawić i uszlachetnić naturę. Na ten temat szerzej zob. Jaeger, W. 2001. Paideia. Formowanie człowieka greckiego. przełożyli M. Plezia, M. Bednarek, Warszawa, s. 388-410.

${ }^{37}$ Protagoras w Platońskim dialogu biorącym tytuł od jego imienia opowiada Sokratesowi przypowieść (mythos) o wyposażeniu człowieka przez Prometeusza, za pomocą kradzieży u Hefajstosa i Ateny, w mądrość potrzebną do życia. Następnym etapem było udzielenie człowiekowi przez Zeusa mądrości politycznej, w skład której wchodziło poczucie sprawiedliwości (dikaiosyne) oraz „wstyd” (aidos) polityczny. Te dwie umiejętności zostały przydzielone wszystkim ludziom, a społeczeństwo ma odpowiednie środki do ich wykorzystania i nagradzania, lub przeciwnie - do ich egzekwowania i karania jednostek, które nie respektują norm życia społecznego (Protagoras 321 c-323 e).

${ }^{38} \mathrm{~W}$ dawnej mentalności greckiej funkcjonowało przyczynowe pojęcie kary, jako boskiej odpłaty za przewinienia ciążące nie tylko na indywidualnym człowieku, ale na całym rodzie (jak w przypadku Edypa i klątwy nad rodem Labdakidów), tymczasem Protagoras głosił nowoczesną teorię kary pojmowanej celowo, jako środek zmierzający do poprawienia złoczyńcy i odstraszenia innych. Zob. Platon, Protagoras $324 \mathrm{a}-\mathrm{b}$. 
rzecz uplasowania się w syndromie Guliwera, ponieważ nagrodą było wejście w rolę duchowego przywódcy, inspiratora społecznego. Drugą, nie mniej ważną przyczyną zabiegania przez sofistów o zaistnienie komfortowych warunków aktu komunikacji, był wzgląd czysto materialny: sofista to płatny nauczyciel, ofiarujący usługi wychowawcze każdemu na zasadzie prywatnego porozumienia, za określoną zapłatą.

Doniosłość wykształcenia udzielanego przez sofistów, prawie z braku bezpośrednich wiadomości, możemy jednak ocenić na podstawie olbrzymiego wpływu, jaki wywarło ono na współczesnych i potomnych. Temu wykształceniu zawdzięczali współcześni mistrzostwo i świadomy kunszt w przemawianiu, układaniu dowodów i w każdej dziedzinie znajdowania słownego obrazu dla myśli, poczynając od najprostszych wypowiedzi a kończąc na wzbudzaniu najgwałtowniejszych emocji przy pomocy środków retorycznych, nad którymi wytrawny użytkownik języka potrafił zapanować niczym pianista nad klawiaturą ${ }^{39}$. Nie byłyby to sukcesy możliwe do odniesienia, gdyby aktualny pozostał wizerunek pitagorejskiego filozofa - mistrza za zasłoną lub „ciemnego filozofa” Heraklita.

Do kwestii dyskusyjnych w nauce należy pojawienie się Sokratesa na tle ruchu sofistycznego.

\section{Wizerunek Sokratesa}

Wprawdzie między filozofią Sokratesa a poglądami sofistów, obarczonych sporą dawką relatywizmu poznawczego i subiektywizmu, najpełniej ujętego w aforystycznej formie przez Protagorasa, lidera ruchu sofistycznego, Człowiek jest miara wszystkich rzeczy (homo mensura), zauważyć musimy istotne różnice, jednak bezsprzecznie fenomen pierwszej sofistyki otwiera drogę filozofii sokratejsko-platońskiej. Ocena pierwszej sofistyki, szczególnie negatywna opinia wystawiona jej przez Platona $^{40}$, zaczęła stopniowo ulegać przewartościowaniu, szczególnie za sprawą prac Wernera Jaegera (Paideia. Formowanie człowieka greckiego) oraz Georga Kerferda (The Sophistic Movement). Istotny dla zrozumienia powiązań między myślą sofistyczną a sokratejsko - platońską jest sąd W. Jaegera:[...] sofiści sa fenomenem tak samo koniecznym, jak Sokrates czy Platon, co więcej, tych ostatnich bez sofistów nie da się pomyślećt ${ }^{41}$.

Wizerunek Sokratesa wymaga przywołania nielingwistycznej kompetencji komunikacyjnej. Jego wygląd zewnętrzny, niedbałe ubranie, bose stopy są manifesta-

\footnotetext{
${ }^{39}$ Jaeger, W., op. cit., s. 405.

${ }^{40} \mathrm{~W}$ zasadzie dialogi Platona tzw. okresu wczesnego, w których głównym rozmówcą jest Sokrates wyrażający poglądy samego Platona, rozprawiają się z sofistyką, np. Gorgiasz, Protagoras, Eutydem, ale także późne dialogi, jak Sofista (tu szczególnie 231 d-e) przedstawiają sofistykę, jako zjawisko niebezpieczne, o zabarwieniu dysfunkcyjnym dla społeczeństwa.

${ }^{41}$ Werner Jaeger, op. cit., s. 380.
} 
cją w celu zwrócenia uwagi na potrzeby intelektualne i duchowe człowieka. Sokrates doskonale wypełnia funkcję transkomunikatora, angażując w akt komunikacyjny modalność wizualno-dotykową oraz wokalno-słuchową. Platon podkreśla, że zewnętrznej brzydocie Sokratesa towarzyszyło piękno duchowe: [...] podobny jest do tych sylenów siedzacych $w$ kapliczkach, których snycerze robia z pozytywka albo fletem $w$ ręku: sylen się otwiera, a w środku posążki bogów ${ }^{42}$, takimi słowami Alkibiades wygłasza pochwałę Sokratesa w Uczcie Platona.

Równocześnie Sokrates miał dar intrygowania słuchaczy swoimi słowami. Niekiedy reakcja była bardzo pozytywna, jak relacjonuje to Alkibiades w Platońskim dialogu Uczta, wygłaszając pochwałę Sokratesa: [...] kiedy ciebie kto stucha albo twoje stowa tylko styszy z drugich ust, choćby je nawet drugi marnie opowiadat, to czy kobieta stucha, czy maż, czy młody chtopiec, wszystkich nas twoja mowa bierze i porywa ${ }^{43}$. Ale Sokrates potrafił też wywołać wściekłość audytorium, rzucano się na niego, bito po twarzy, szarpano za włosy ${ }^{44}$. Najczęściej jednak był przedmiotem drwin i pogardy, które znosił cierpliwie. Diogenes Laertios opowiada o sytuacji, kiedy Sokrates nie zareagował na kopniaka, którym go uraczono. A kiedy jeden ze świadków sceny zdziwił się spokojowi Sokratesa, ten odpowiedział: A gdyby kopnąt mnie osiot, czy pozwatbym go przed są $?^{45}$. Oryginalną wartością filozofii Sokratesa jest troska o sprawy duchowe (epimeleia tes psyches). Sokrates wywoływał gwałtowne i nieprzychylne reakcje, ponieważ odwracał skalę wartości greckich: dobra duchowe stawiał ponad dobrami fizycznymi i ponad tzw. dobrami zewnętrznymi, takimi jak sława, bogactwo, zaszczyty, co stanowiło zaprzeczenie popularnego wartościowania, przekazanego przez greckie skolion, piosenkę śpiewaną przy winie:

$$
\begin{aligned}
& \text { Zdrowie - to pierwszy skarb śmiertelnych ludzi } \\
& \text { Drugi-to rosta postać mieć } \\
& \text { Trzeci - wzbogacić się uczciwie } \\
& \text { A czwarty - dobrej myśli być w przyjaciót gronie }
\end{aligned}
$$

Do tego ciasnego kręgu wartości cenionych przez człowieka greckiego przybywa za sprawą Sokratesa nowa koncepcja wewnętrznego ładu w człowieku: arete, o której mówi Sokrates, jest wartością duchową, określoną przez niego terminem psyche, dusza. Psyche Sokratejska nie ma jednak wymiaru religijnego, jaki my obecnie przypisujemy temu pojęciu, wychowani w kulturach monoteistycznych, ma raczej charakter intelektualno-moralny ${ }^{47}$. Ten aspekt rozumienia psyche widać rów-

\footnotetext{
${ }^{42}$ Platon, Uczta (215 b), przełożył Władysław Witwicki, Warszawa 1984.

${ }^{43}$ Ibidem, $215 \mathrm{~d}$.

${ }^{44}$ Relacja Diogenesa Laertiosa w Żywotach i pogladach stynnych filozofów, op. cit., ks. II, rozdz. 5, 21.

${ }^{45}$ Ibidem, s. 88, ks. II, rozdz. 5, 21.

${ }^{46}$ Skolion pochodzi z Antologia Lyrica Graeca, t. II, s. 183.

${ }^{47}$ Pod koniec dialogu Obrona Sokratesa Platon wkłada w usta Sokratesa słowa o wydźwięku agnostycznym: Otóż jednym z dwóch jest śmierć. Bo albo tam niejako nic nie ma i człowiek po śmierci nawet
} 
nież w metodzie majeutycznej Sokratesa, której towarzyszyło jego optymistyczne przekonanie, że nikt nie błądzi dobrowolnie (gr. ouden hekos hamartanei, łac. nemo sua sponte peccat). Człowiek sprowokowany do myślenia za pomocą zadawanych mu pytań i jego, coraz precyzyjniejszych odpowiedzi, ,poprawia” swoje przekonania w sferze moralnej, co przekłada się na jego lepsze uczynki w życiu społecznym. To stanowisko nazywamy intelektualizmem etycznym, akcentując element rozsąd$\mathrm{ku}$, phronesis, w etycznym postępowaniu człowieka. Sokrates przez pojęcie psyche nie zamierzał też przeciwstawiać sobie „duchowości” i „cielesności”: jego pojęcie duszy można zrozumieć, gdy traktuje się ją na tym samym planie, co ciało, ale widzi się w każdym z nich jedną z dwu różnych stron tej samej natury ludzkiej ${ }^{48}$. Jest to nowe spojrzenie na naturę, physis, które zaowocuje u ucznia Sokratesa, Antystenesa, stworzeniem podwalin nauki cynickiej. Zresztą także forma uprawiania filozofii przez Sokratesa, jego protreptyczne wypowiedzi, zachęcające obywateli do troski o duszę, dały początek popularno-filozoficznej diatrybie cynickiej.

Sokrates, przekonany o wartości głoszonych przez siebie opinii, gotów był narazić się nie tylko na zarzut śmieszności, ale nawet na upokorzenie procesem sądowym i karę śmierci. Dla pouczenia moralnego, ulepszenia człowieka, przyjmował w akcie komunikacji syndrom Guliwera: mówił językiem prostym i łatwym do zrozumienia, gdy rozprawiał z obywatelami ateńskimi na agorze czy w innych miejscach komunikacji publicznej. Jednym ze świadectw sposobu komunikowania się Sokratesa z mieszkańcami Aten są jego słowa przekazane przez Platona z początkiem Obrony Sokratesa: [...] ustyszycie stowa proste, wyrazy takie, jakie sie nawina. [...] jeżeli ustyszycie, że ja bronię się takimi samymi stowami, jakimi zwykle mówię i na rynku obok straganów, gdzie mnie niejeden z was widziat, i gdzie bądź indziej, nie dziwcie się i nie róbcie hałasów dlatego ${ }^{49}$. Nawet $\mathrm{w}$ obliczu kary śmierci, przewidzianej w przypadku zarzucanej mu bezbożności, Sokrates nie zdecydował się na zmianę sposobu wypowiedzi. Zrósł się on na zawsze z jego wizerunkiem i stanowi niejako znak rozpoznawalny Sokratesa jako filozofa. Metoda majeutyczna, która służyła „rodzeniu się” lepszych określeń i wypracowywaniu definicji ${ }^{50}$, podporządkowana była nadrzędnemu celowi - utrzymania więzi komunikacyjnej z „badanym” w dyskusji.

Sokrates posiadał także poczucie humoru oraz dystans do własnej osoby. Świadectwem tego jest przekazana przez Ksenofonta w dialogu Uczta relacja z konkursu

wrażeń żadnych nie odbiera, albo jest to, jak mówią, przeobrażenie jakieś i przeprowadzka $w$ inne miejsce (40 d). Przekład Władysława Witwickiego.

${ }^{48}$ Zob. Jaeger, W., op. cit., s. 595.

${ }^{49}$ Platon, Obrona Sokratesa (17 c) w przekładzie Władysława Witwickiego. Sokrates broni swojego sposobu komunikacji przed zarzutem braku ozdobności i manieryzmu retorycznego, do których przyzwyczajeni byli obywatele ateńscy w sądach ludowych.

${ }^{50}$ Arystoteles w Metafizyce (987 b) oraz Ksenofont we Wspomnieniach o Sokratesie (IV, 6, 1) poświadczają umiejętności dialektyczne Sokratesa i uznają jego zasługi w tworzeniu definicji pojęć. 
piękności między Sokratesem a znanym z urody młodym Kritobulosem. Sokrates w konkursie tym przyjmuje kryterium sofistyczne „tego, co piękne” (kallos), jako „tego, co użyteczne”, to znaczy lepiej przystosowane do stawianych rzeczy zadań, sugerowane przez Kritobulosa ${ }^{51}$. W wyniku badania przeprowadzonego przez Sokratesa (dialegesthai) okazuje się, że wyłupiaste oczy Sokratesa, jako wystające z orbit, widzą nie tylko to, co przed nim, ale też z boku. Podobnie zadarty nos Sokratesa pozwala zewsząd chłonąć zapachy, a nadto nie przegradza oczom pola widzenia. Usta zaś, grube i duże, umożliwiają nie tylko odgryzanie większych kęsków jedzenia, ale sprawiają też, że pocałunki Sokratesa są bardziej miękkie niż Kritobulosa. Dopełnieniem tej satyrycznej diagnozy jest przysunięcie lampy bliżej Kritobulosa, aby sędziowie konkursu nie popełnili omyłki. Sokrates przegrał w głosowaniu, a jego przegrana jest zarówno przegraną sofistycznego kryterium użyteczności, jak też wygarną metody dyskusji, której używa Sokrates i którą wciąga w badanie zagadnienia Kritobulosa oraz wszystkich uczestników biesiady. Jest to zwycięstwo Sokratesa jako transkomunikatora, posługującego się także środkami wizualno-dotykowymi, które towarzyszą i wspierają środki werbalne. Poza tym scenka przekazana przez Ksenofonta ujawnia poczucie humoru, jakie towarzyszyło Sokratesowi i jego gotowość do ośmieszenia zewnętrznego wizerunku, jeśli stawką jest weryfikacja wewnętrznego wizerunku. Sokrates korzysta w sposób w pełni świadomy z możliwości, jakie stwarza diada „wygląd-ogląd”, a jego celem jest uświadomienie współczesnym mu Ateńczykom, że wnętrze człowieka stanowi o prawdziwym jego pięknie i wartości.

Zarówno forma dialogowa, jak też doza humoru i ironii, jako narzędzia służące kreowaniu wizerunku, okażą się bardzo użyteczne dla metody kontaktu z audytorium reprezentatywnej dla cyników, których protoplastą jest Antystenes, uczeń Sokratesa, a symbolem filozof z beczki, czyli Diogenes z Synopy.

\section{Wizerunek cynika}

Wraz z upadkiem greckiej polis pojawiły się w filozofii nowe problemy i kategorie pojęciowe. Aleksander swoją śmiałą wizją kosmopolitycznego mocarstwa położył kres istnieniu polis w sensie faktycznym i teoretycznym. Grek, który utożsamiał się z obywatelem i pojmował swoje obowiązki etyczne i polityczne w granicach miasta-państwa ${ }^{52}$, znalazł się w impasie moralnym. Z obywatela stał się zwykłym poddanym, a decyzje polityczne były podejmowane bez jego udziału.

${ }^{51}$ Kritobulos przytacza kryterium użyteczności na początku dyskusji z Sokratesem: [Piękne sq rzeczy], jeżeli sa tak dobrze wykonane, że stuża celom, do jakich je posiadamy, albo jeśli z natury sa znakomicie przystosowane do naszych potrzeb. Ksenofont, Pisma sokratyczne, przełożył i wstępem poprzedził Leon Joachimowicz, Warszawa 1967, Uczta 5, 4, s. 277.

${ }^{52}$ Dla Arystotelesa etyka stanowiła część polityki. Por. Reale, G., Historia filozofii starożytnej, t. II, s. 475: Arystoteles nazywa nawet ogólnie 'politykq' naukę obejmująca ogót działań moralnych 
Filozofia nowych czasów umieszcza państwo i politykę w rzeczach neutralnych, obojętnych, albo nawet wśród rzeczy moralnie negatywnych, ponieważ są źródłem ambicji, namiętności, trosk i zbędnych niepokojów. Znika też optymizm poprzedniej epoki. W nowej rzeczywistości politycznej pojawiają się w filozofii tony pesymistyczne, sugerujące brak poczucia bezpieczeństwa, a jednak filozofia ta straciwszy dawne zainteresowania i horyzonty zyskała na zasięgu swojego oddziaływania. Filozofowie stają się lepszymi transkomunikatorami, nauczają na rozstajach dróg, jak cynicy uprawiający diatrybę, prozatorską moralistykę, silnie retoryzowaną, z użyciem charakterystycznych dla diatryby loci, typu locus de divitiis (topos bogactwa), locus de fato (topos przeznaczenia), locus de morte (topos śmierci) i wiele innych, interesujących dla silnie zróżnicowanego pod względem intelektualnym, wiekowym, społecznym audytorium. $\mathrm{Z}$ diatryby, czyli cynickiego wykładu moralizatorskiego, w założeniu komunikatora, powinna płynąć przyjemność słuchania (delectatio) ${ }^{53}$. Jednak zagadnienie jest o wiele bardziej złożone, ponieważ cynikami, jako transkomunikatorami, kierowała zasada wsparcia słuchaczy, wskazania im treści moralnych, nowych celów życia, dydaktyzm, ale nie nachalny, raczej ,uzdrawiające duszę" leczenie za pomocą zarówno słowa, jak też dopełniającego go wizerunku zewnętrznego filozofa cynickiego. Cynicy przedstawiali sami swój ruch jako filozofię misjonarską ${ }^{54}$, co znajduje odzwierciedlenie w terminologii, którą określali swoją funkcję w przestrzeni publicznej: paidagogos, didaskalos (,nauczyciel”, „wychowawca”), iatros („lekarz” domyślne: dusz), archon („przywódca”), euergetes („dobroczyńca”), episkopos („opiekun”). Wszystkie one mają odcień znaczeniowy przewodnika moralnego, którego celem jest nawrócenie na cynicką drogę życia, tzw. kynikos bios. W tekstach cynickich znajdujemy często wzmianki o tym, że filozofom tym towarzyszą rzesze uczniów, a oni sami ze swej strony ofiarują głęboką życzliwość, philanthropia ${ }^{55}$ i wyświadczają tym, którzy chcą się nawrócić dobrodziejstwo (euergesia). Jest to świadectwem zamierzonego i celowego działania, potrzebnego w nowej kondycji ludzkiego losu. Cynicy negowali instytucje państwowe, pojęcia patris, polis, politeia (wszystkie związane z organizacją życia społeczno-politycznego) były w ich mniemaniu obrazem fałszywego kosmosu, któremu przeciwstawiali prawdziwy kosmos „cynickiego państwa”, które było po prostu państwem moralnym $^{56}$. Cynik mógł żyć w każdym miejscu na „,całej ziemi”, która była jego domem.

\footnotetext{
ludzi, zarówno jako jednostek, jak i jako obywateli państwa; potem dopiero dzieli tak rozumiana „politykę" odpowiednio na etykę i politykę w sensie ścistym (teoria państwa).

${ }^{53}$ Sinko, T. 1947. Literatura grecka. Tom 2, część 1. Kraków, s. 18.

${ }^{54}$ Terminem missionary philosophy operuje w stosunku do cyników John Moles w artykule Cynic Cosmopolitanism, [w:] The. Cynics. The Cynic Movement in Antiquity and Its Legacy, red. R.B. Branham and M-O. Goudet-Cazé, Los Angeles 1996, s. 114.

${ }^{55}$ Tuszyńska, K. 2013. Dyskurs Diona z Prusy w „Mowach o królestwie”. Mariaż retoryki z filozofia. Poznań, s. 83.

${ }^{56}$ John Moles, op. cit., s. 111.
} 
Warunkiem wszakże niezbędnym było poddanie się trudom narzuconym przez naturę, zdolnym zahartować ciało oraz ćwiczeniom fizycznym i duchowym (askesis), których celem jest zapanowanie nad przyjemnościami, a nawet pogardzanie nimi, co $\mathrm{w}$ rezultacie gwarantuje człowiekowi wolność. [Diogenes] mówit, że w życiu w ogóle nie można nic osiagnać bez ćwiczenia. Ćwiczenie zaś pomaga wszystko przezwyciężyć. Ażeby żyć szczęśliwie, należy zamiast trudów niepotrzebnych wybrać tylko trudy zgodne z natura: nieszczéście wynika tylko z braku rozumu ${ }^{57}$. Cynicki filozof realizował ideał autarkii, czyli wystarczania samemu sobie, niepotrzebowania niczego $\mathrm{z}$ dóbr materialnych, $\mathrm{w}$ czym cynik naśladował zwierzę.

Symbolem braku potrzeb materialnych jest zewnętrzny wizerunek filozofa cynickiego: jeden płaszcz, składany na dwoje, w celu posłania, torba, w której cynik miał chleb, podróżny kij, którym podpierał się w wędrówce w celu głoszenia nauki i nawracania słuchaczy na drogę kynikos bios ${ }^{58}$. Miernikiem wartości cynickiego życia było osiągnięcie wolności, która przejawiała się w wolności słowa (parrhesia). Wraz z szczerością w mówieniu Diogenes głosił szczerość (wolność) w działaniach (anaideia), niekiedy świadomie przejaskrawioną, celem pokazania czysto konwencjonalnego charakteru zwyczajów i obyczajów ${ }^{59}$.

Diogenes, który stał się symbolem ruchu cynickiego, zburzył klasyczny obraz człowieka greckiego, a nowy, który zaproponował, szybko uznany został za paradygmat. Jego słynne zdanie „szukam człowieka” wypowiedziane, gdy chodził z zapaloną latarnią w centrum miasta w dzień (Diogenes Laertios, ks. VI, 2, 41), oznaczało, że szuka człowieka i nie znajduje takiego, który żyje w zgodzie ze swoją najbardziej istotną cechą, to znaczy - w zgodzie ze swoją naturą, poza konwenansami narzuconymi przez społeczeństwo, nie bacząc na kaprysy losu i fortuny, szczęśliwy, bo rozumny, rozumny, bo cnotliwy.

Jak wspomniałam, filozofowie cyniccy byli twórcami nowego gatunku literackiego, diatryby, której odbiorcami był szeroki krąg słuchaczy. Wymienione, „,miejsca wspólne", loci, w ustnym przekazie cynika były decydujące dla nawiązania nici porozumienia między komunikatorem a zróżnicowanym audytorium. Definicja diatryby, w ujęciu Hermogenesa, brzmi: rozwinięcie jakiejś krótkiej myśli moralnej $w$ taki sposób, aby usposobienie mówcy utrwalić w duszach stuchaczy ${ }^{60}$. Cytat ten wskazuje, że cynikom, jako filozofom, chodziło nie o proste dostarczenie przyjemności ze słuchania wykładu (wspomniane delectatio), ale o wytworzenie porozumienia o charakterze psychologicznym między nadawcą a odbiorcą. Cynicy dążyli swymi diatrybami do tego, aby słuchacz wyrobił sobie sąd moralny pokrywający się z sądem komunikatora. Cechą diatryby jest łączenie powagi z komizmem (gr. spou-

\footnotetext{
${ }^{57}$ Diogenes Laertios, op. cit., ks. VI, 70 I n.

${ }^{58}$ O wizerunku zewnętrznym Diogenesa z Synopy pisze Diogenes Laertios, op. cit., ks. VI, 22 i n.

${ }^{59}$ Reale, G. 1999. Historia filozofii starożytnej, tom III. przeł. E.I. Zielińsk. Lublin, s. 48.

${ }^{60}$ Epiktet, Diatryby, Encheiridion, przełożył i opracował Leon Joachimowicz, Warszawa 1961, Wstęp, s. XIV.
} 
daiogelaion), wplatanie anegdot, przykładów, złotych myśli, przysłów mądrości ludowej, dowcipów, ale także cytatów z poetów, filozofów, gier słownych, ironii, czy sarkazmu ${ }^{61}$. Szeroki wachlarz środków przekazu stwarzał cynikom możliwości komunikowania się na wysokim stopniu fortunności z rozmaitymi grupami słuchaczy. Bardziej wyrobiony intelektualnie słuchacz docenił cytaty filozoficzne, poetyckie, grę słów, prosty odbiorca zainteresował się anegdotą, z satysfakcją odnalazł mądrość ludową lub przysłowie. Wszystkie elementy układanki, jaką jest diatryba cynicka, sprawiały, że komfortowość aktu komunikacji nie była ograniczona. Popularna diatryba cynicka wyklucza abstrakcję i teorię, opiera się na konkretach, rozmówca jest zazwyczaj fikcyjny, bliżej nieokreślony „ktoś”, kto zadaje pytania, na które odpowiada autor, co nadaje diatrybie charakter dialogu pozornego. Ten element stanowi spadek po filozofii Sokratesa. Podobnie, jak w wypadku Sokratesa, filozof - cynik świadomie przyjmował model Guliwera, realizując zasadnicze przesłanie filozofii nowych czasów - udzielenie wszystkim szukającym wsparcia duchowego, uwolnienie od niepokojów, zaproponowanie nowego modelu życia. $\mathrm{W}$ tym ostatnim zadaniu filozofa cynickiego dostrzegamy zadania społeczne, jakie zaczyna stawiać przed sobą filozofia, wcześniej głoszona „za zasłoną”, lub z udziałem świadomie wybranej ciemnej syntaksy, lub zamknięta za murami elitarnych szkół - Akademii Platona, Liceum Arystotelesa. Nawet, jeśli od okresu hellenistycznego począwszy, powstają szkoły filozoficzne, po pierwsze - dają one schronienie każdemu, kto o to prosi, po drugie - wprowadzają nauki w życie, a tym samym budują zupełnie osobliwą relację między filozofem, który naucza a słuchaczem, który przychodzi do niego jako jednostka prywatna, szukająca indywidualnego szczęścia ${ }^{62}$.

Z filozofii cyników wyrósł stoicyzm, również kierunek kosmopolityczny, którego idea pięknie uzewnętrznia się w słowach rzymskiego mówcy i filozofa, Cycerona: [...] naturalna jest także powszechna życzliwość wzajemna pomiędzy ludźmi, tak iż człowiek - właśnie dlatego, że jest człowiekiem, nie może patrzeć na drugiego czlowieka jako na coś obcego ${ }^{63}$.

\section{Zakończenie}

Z przedstawionych wizerunków filozofa greckiego wynika, że ulegał on zmianie, odpowiadał za oczekiwania, stosował się do wymogów czasu. Myśl filozoficzna nie powstaje w próżni, ale komentuje rzeczywistość, z której wyrasta. Każdy z wize-

\footnotetext{
${ }^{61}$ Ibidem.

${ }^{62} \mathrm{O}$ nowym ethosie w szkołach hellenistycznych zob. Reale, G. Historia filozofii starożytnej, tom III, op. cit., s. 188.

${ }^{63}$ Cyceron, De finibus bonorum et malorum (O najwyższym dobru $i$ złu) III, 19, 62 i n. w przekładzie W. Kornatowskiego. Cytat za Reale, G. Historia filozofii starożytnej, t. III, op. cit., s. 426.
} 
runków filozofa jest obrazem transformacji duchowych człowieka greckiego w miarę rozwoju cywilizacji. Pierwsi filozofowie greccy pielęgnowali wizerunek mędrca (sophos), niechętnie stając się transkomunitorami z syndromem Guliwera. Heraklit, czy Pitagoras świadomie pozostawali niedostępni dla powszechnego odbioru, z wyższością czy pogardą odnosząc się do „ciemnego ludu”. Nie schodził ze swego piedestału także Platon, który ustanowił hierarchię bytów: na czele Jedno i Diada ${ }^{64}$, następnie świat idei, potem poziom „bytów matematycznych” i na końcu świat zmysłowy, dla którego nie miał zrozumienia, jako dla niedoskonałego odbicia świata idei poznawalnego za pomocą dialektyki. O teorii zasad rozmawiał tylko w ścisłym kręgu uczniów, którzy po długim i intensywnym przygotowaniu matematycznodialektycznym byli zdolni przyswoić sobie naukę mistrza. W tym z pewnością, podobnie jak Heraklit, Pitagoras, wykazywał syndrom Petroniusza. Stając jednak do walki z sofistami, postanowił upublicznić swoją naukę. Arystoksenos opowiada anegdotę o wrażeniach, jakie odniosły szerokie koła słuchaczy, gdy przyszli oni wysłuchać Platońskiego wykładu O Dobru: Każdy przyszedt, aby móc się dowiedzieć o jednej z tych rzeczy, które uważane sq za dobre dla ludzi, jak bogactwo, $z$ drowie, sita, $i$ w ogóle wspaniate szczęście. Kiedy jednak okazato się, że wywody dotyczyly spraw matematycznych, liczb, geometrii i astronomii, a w końcu się twierdzito, że istnieje Dobro, Jedno, to saqdzę, że wydato się to czymś zupetnie paradoksalnym. W konsekwencji niektórzy wykładem wzgardzili, inni go skrytykowali ${ }^{65}$. Próba ogłoszenia wyników swoich badań w przestrzeni publicznej skończyła się w przypadku bezpośredniego kontaktu z odbiorcą porażką dla Platona. Podjął jednak jeszcze próbę literacką, tworząc nowy gatunek ,dialog” i wprowadzając swego mistrza, Sokratesa, jako rozmówcę. Można powiedzieć, że tym samym Platon zrobił krok w kierunku komunikatora typu Guliwera, jednak w Fajdrosie i Liście Siódmym precyzyjnie zastrzegł, że pismu należy przypisywać tylko ograniczoną wartość, ponieważ jest jedynie środkiem przywoływania na pamięć rzeczy już znanych.

\footnotetext{
${ }^{64}$ Diada jest „,nieokreśloną dwoistością”, zasadą i źródłem wielości bytów. Bez Diady nie może być pomyślna w świecie wielość. Jedno nie miałoby mocy twórczej bez Diady, ale w hierarchii Jedno stoi nad Diadą

${ }^{65}$ Anegdota opowiedziana za Reale, G. 1996. Historia filozofii starożytnej, tom II, przekład E.I. Zieliński, Lublin. s. 44.
} 